\title{
PENGARUH METODE SOSIODRAMA TERHADAP KEMAMPUAN KOMUNIKASI VERBAL ANAK DENGAN TUNAGRAHITA DI PAUD DHARMA WANGSA DENPASAR BARAT
}

\author{
Kadek Maya Puspa Dewi ${ }^{1}$, Luh Ayu Tirtayani ${ }^{2}$, I Wayan Sujana ${ }^{3}$ \\ 1,2 Jurusan Pendidikan Guru Pendidikan Anak Usia Dini \\ 3 Jurusan Pendidikan Guru Sekolah Dasar \\ Fakultas IImu Pendidikan \\ Universitas Pendidikan Ganesha \\ Singaraja, Indonesia
e-mail: mayapuspadewi17@yahoo.com¹ , ayu.tirtayani@undiksha.ac.id², iwayan.sujana@undiksha.ac.id ${ }^{3}$

\begin{abstract}
Abstrak
Penelitian ini bertujuan untuk mengetahui pengaruh metode sosiodrama terhadap kemampuan komunikasi verbal anak tunagrahita kelompok A di PAUD Dharma Wangsa Denpasar Barat. Jenis penelitian ini adalah rancangan eksperimen kasus tunggal dengan 1 subjek anak dengan tunagrahita dalam kategori ringan yang memiliki IQ 58 pada skala Binet. Penelitian ini dilaksanakan dalam tiga fase, yaitu fase baseline (A1), fase perlakuan/treatment (B), dan fase baseline (A2). Data dikumpulkan menggunakan metode observasi dengan instrumen lembar observasi berupa checklist. Data hasil penelitian dianalisis menggunakan metode analisis statistik deskriptif dan penyajian data dipaparkan secara visual (visual inspection). Hasil analisis data menunjukkan kecenderungan membaik kemampuan komunikasi verbal subjek yang terlihat dari adanya peningkatan kemampuan komunikasi verbal subjek dari fase baseline (A1) dengan rerata 25,8 menjadi 60,6 pada saat diterapkannya treatment pada fase penerapan (B), dan pada fase baseline (A2) saat penerapan metode sosiodrama dihentikan dengan rerata 44,4. Rentangan stabilitas penelitian ini pada fase baseline (A1) sebesar $60 \%$, fase treatment (B) sebesar $80 \%$, serta fase baseline (A2) sebesar $60 \%$. Berdasarkan hasil penelitian tersebut, dapat disimpulkan bahwa metode sosiodrama berpengaruh terhadap peningkatan kemampuan komunikasi verbal pada anak tunagrahita di PAUD Dharma Wangsa Denpasar Barat.
\end{abstract}

Kata-kata kunci: sosiodrama, komunikasi verbal, anak dengan tunagrahita

\begin{abstract}
This study aimed to determine the effect of the sociodrama method on verbal communication ability of children with mental retardation group A in Dharma Wangsa Kindergarten, West Denpasar. Kind of this research is single case experimental design with 1 subject of mental retardation in the mild category that has an IQ of 58 on the Binet scale. This research was implemented in three phases which are the baseline phase (A1), the intervensi phase (B), and the baseline phase (A2). The collection of data research using observation with instrument checklist observation. Data of research result were analyzed using descriptive statistical analysis method and data are presented visually (visual inspection). The result of data analysis showed a tendency to improve the subject's verbal communication skills, as evidenced by the increase verbal communication skills from baseline phase (A1) with a mean of 25,8 to 60,6 in the implementation phase of treatment (B), and baseline phase (A2) when the implementation of the sociodrama method is stopped with a mean 44,4 . The range of stability of this study at the baseline phase of $60 \%$, treatment phase (B) of $80 \%$, and baseline phase (A2) of $60 \%$. Based on these results it can be concluded that the sociodrama method affects verbal communication in the child's with mental retardation in Dharma Wangsa Kindergarten, West Denpasar.
\end{abstract}

Keywords : sociodrama, verbal communication, mental retardation 


\section{PENDAHULUAN}

Pendidikan inklusi merupakan perkembangan baru dari pendidikan terpadu. Pada sekolah inklusif setiap anak sesuai dengan kebutuhan khususnya, semua diusahakan agar dapat dilayani secara optimal dengan melakukan berbagai modifikasi dan atau penyesuaian mulai dari kurikulum, sarana-prasarana, tenaga pendidikan dan kependidikan, sistem pembelajaran sampai sistem penilaiannya (Nuraeni, 2014:397). Dalam Peraturan Menteri Pendidikan Nasional (Permendiknas) Nomor 70 Tahun 2009 disebutkan bahwa yang dimaksud dengan pendidikan inklusi adalah sistem penyelenggaraan pendidikan yang memberikan kesempatan kepada semua peserta didik yang memiliki kelainan dan memiliki potensi kecerdasan dan/atau bakat istimewa untuk mengikuti pendidikan atau pembelajaran dalam lingkungan pendidikan secara bersama-sama dengan peserta didik pada umumnya. Selain PAUD yang dikenal pada umumnya, seiring berjalannya waktu adapun PAUD inklusi.

Pendidikan Anak Usia Dini (PAUD) inklusi merupakan PAUD yang diperuntukkan bagi anak usia dini yang memiliki kelainan atau kecerdasan istimewa, yang didalamnya mencakup pendidikan inklusi bagi anak berkebutuhan. Konsep dasar pendidikan inklusif dimaksudkan sebagai sistem layanan pendidikan yang mengikut sertakan anak berkebutuhan khusus belajar bersama dengan anak sebayanya di sekolah regular yang dekat dengan tempat tinggalnya. Sementara semangat penyelenggaraan pendidikan inklusi adalah memberikan kesempatan atas akses yang seluas-luasnya kepada semua anak untuk memperoleh pendidikan yang bermutu dan sesuai kebutuhan individu peserta didik tanpa diskriminasi (Mastuti, 2014:3). Pentingnya PAUD bagi ABK (Anak Berkebutuhan Khusus) adalah untuk memotivasi dan memberikan pembelajara pada anak berkebutuhan khusus, sehingga nantinya anak berkebutuhan khusus tersebut dapat mengembangkan segala kemampuan yang dimilikinya semaksimal mungkin. PAUD inklusi adalah PAUD yang mengoordinasi dan mengintegrasikan anak PAUD dan anak penyandang cacat dalam program yang sama awal dari mempersiapkan pendidikan bagi anak penyandang cacat yang mempunyai kemampuan di atas anak-anak difabel lainnya, baik dalam tingkah laku maupun mengenai pentingnya pendidikan inklusi tidak hanya memenuhi target pendidikan untuk semua tetapi juga pendidikan dasar.

Pembelajaran pada PAUD inklusi pun dikhususkan sesuai dengan permasalahan yang dihadapi anak dan sejauh mana tingkat perkembangan anak. Sebagai guru/pengelola PAUD, belajar memahami arti kebersamaan untuk anak didik dan memberi motivasi kepada anak didik non ABK untuk menerima adanya keberagaman dalam pembelajaran hal ini sebagai proses pengembangan sosialisasi bagi anak. Untuk menerima anak ABK, sebagai pengelola/guru memberi peluang mereka mengikuti pembelajaran dengan waktu pembelajaran di kelas yang tidak begitu lama dan pembelajaran yang bertahap. Namun, dalam praktiknya sistem pendidikan inklusi masih menyisakan persoalan tarik ulur antara pihak pemerintah dan praktisi pendidikan, erat kaitannya pada guru-guru.

Berbagai permasalahan tentunya dihadapi oleh anak-anak berkebutuhan salah satunya adalah kemampuan berkomunikasi pada anak berkebutuhan. Komunikasi merupakan modal utama bagi seseorang dalam berinteraksi dan beradaptasi baik dalam lingkungan sekitarnya maupun lingkungan luar. Untuk mengembangkan kemampuan berkomunikasi pada seorang anak normal dapat dilakukan sesuai tahap perkembangan dan kebutuhan anak dengan memberi stimulasi yang mampu merangsang perkembangan berkomunikasinya, tetapi lain halnya dengan anak berkebutuhan khusus seperti tunagrahita dimana anak dengan tunagrahita memiliki kecerdasan dibawah rata-rata yang membuatnya sulit menerima pesan yang disampaikan seseorang baik secara verbal maupun nonverbal. Tunagrahita merupakan kata lain dari retardasi mental (mental retardation) yang artinya terbelakang mental (Yosiani, 2014:112). Retardasi mental ditandai dengan fungsi intelektual dibawah rata-rata 
disertai dengan ketidakmampuan fungsi adaptasinya.

Tunagrahita merupakan istilah yang digunakan di Indonesia saat ini bagi anak yang sangat jelas terhambat dalam perkembangan kecerdasannya dibandingkan dengan teman-teman sebayanya, sehingga memerlukan layanan pendidikan secara khusus. Anak tunagrahita adalah anak yang mengalami hambatan dalam perkembangan mental dan intelektual sehingga berdampak pada perkembangan kognitifnya. Istilah tunagrahita adalah sebutan bagi mereka yang mengalami keterbelakangan mental, feeble mindedness (lemah pikiran), mental subnormality, cacat mental, deficit mental, bodoh, dungu, pandir (imbecile), tolol (moron), oligofrenia (oligophrenia), mampu didik (educable), mampu latih (trainable), ketergantungan penuh (totally dependent), atau butuh rawat, mental subnormal, deficit mental, deficit kognitif, cacat mental, defisiensi mental, serta gangguan intelektual. Tunagrahita disebut juga retardasi mental (mental retardation). Istilah anakk tunagrahita dapat dipahami sebagai bentuk keterbatasan substansial dalam memfungsikan diri (Aziz, 2015:86). Siswa yang digambarkan sebagai anak terbelakang mental mampu latih (trainable mentally retarded) dianggap mampu belajar hanya beberapa kata terpisah dan kemampuan menghitung yang terbatas. Mereka dianggap mampu menjadi individu semi-mandiri. Adapun beberapa perkembangan yang menghambat kemampuan anak dengan retardasi mental, yaitu keterlambatan dalam kemampuan komunikasi dengan mengucapkan bahasa atau kata-kata sederhana. Kelainan bahasa dapat terjadi bila anak-anak mempunyai kesulitan dalam mengembangkan dan menggunakan bahasa, bukan mengeluarkan ucapan. Kelainan bahasa pada anak-anak seringkali berhubungan dengan keterlambatan bicara (delayed speech). Keterlambatan bicara dihubungkan dengan ketidakmatangan pertumbuhan lain dalam diri anak, yang mungkin dibarengi dengan perkembangan terbelakang mental, ketidakstabilan emosi, autis, atau cidera otak (Smith, 2006:212). Pada anak tunagrahita dengan kategori ringan, memiliki kemampuan bahasa, pemusatan pikiran, dan akademik yang kurang. Tetapi dalam kategori ini anak tunagrahita masih dapat belajar membaca, menulis dan berhitung sederhana.

Anak dengan hambatan kecerdasan ringan banyak yang lancar berbicara tetapi kurang perbendaharaan kata-katanya. Anak ini miskin dalam perbendaharaan katanya, sehingga cenderung kurang menggunakan komunikasi verbal dengan baik dan benar. Dengan demikian pembelajaran bahasa perlu diberikan secara intensif. Anak tunagrahita cenderung memperlihatkan adanya gangguan artikulasi. Anak-anak ini menunjukkan kesulitan pada aspek fonologis yang dapat berkaitan dengan keterlambatan perkembangan merabannya dan bisa juga diakibatkan keterlambatan perkembangan bahasanya secara umum.

Abdurahman

(2017:62),

mengemukakan bahwa "perkembangan bahasa erat kaitannya dengan kognisi, keduanya mempunyai hubungan timbal balik. Telah diketahui bahwa anak tunagrahita ringan memiliki keterbatasan dalam aspek intelegensi, sehingga mereka sering tertinggal dalam perkembangan bahasanya". Mengingat pentingnya kemampuan mengungkapkan bahasa lisan dalam proses komunikasi, maka hal yang perlu diperhatikan adalah bagaimana seorang anak memperoleh kemampuan bahasa. Anak tunagrahita memiliki permasalahan yang begitu kompleks dilihat dari segi aspek perkembangan anak usia dini. Seperti yang telah dipaparkan, bahwa salah satu permasalahan anak tunagrahita yaitu pada kemampuan berbahasa. Kemampuan dan keterampilan berbahasa memiliki peranan yang begitu penting sebagai bekal anak untuk melanjutkan kehidupannya. Seperti yang telah diketahui bahwa anak tunagrahita memiliki perbendaharaan kosa kata yang sangat kurang, dengan demikian pemahaman anak tunagrahita terhadap kemampuan berbahasa sangat sedikit.

Berdasarkan observasi dari tanggal 7 Pebruari sampai dengan 21 Pebruari 2018 yang dilakukan di PAUD Dharma Wangsa, sesuai fakta yang ditemukan bahwa anak dengan tunagrahita memiliki kesulitan dalam berkomunikasi terutama mengungkapkan sesuatu dengan bahasa lisan. 
Terhambatnya kemampuan bahasa lisan dapat disebabkan oleh berbagai faktor salah satunya kurangnya stimulasi khusus yang diberikan pada tempat anak mendapatkan pendidikan tersebut sehingga menyebabkan pemerolehan kosa kata anak kurang dan kemampuan berbahasanya pun kurang, serta kurangnya strategi dan metode yang digunakan dalam setiap pembelajaran yang menyebabkan anak menjadi bersikap pasif. Pembelajaran sehari-hari anak dengan tunagrahita yang disertai dengan strategi atau metode yang tepat akan memberikan pengalaman dan banyak kosa kata baru yang didapatnya. Dalam pembelajaran dikelas pada kelompok $A$ terdapat 3 orang anak dengan kemampuan dan perkembangan yang berbeda, tetapi anak dengan tunagrahita ini memiliki kemampuan yang dibawah rata-rata dibanding dua anak lainnya pada kelompok $A$. Pada setiap pembelajaran di kelas anak mau berbaur mengikuti dan taat terhadap aturan maupun perintah guru bersama dengan kedua temannya. Kemampuan berbahasa secara verbal anak masih sangat kurang akibat rendahnya kosa kata yang dipahami dan dimilikinya, tetapi kemampuan bahasa nonverbal sudah sangat baik dilihat dari gestur anak dalam berekspresi tertawa, bingung, cemas, sedih, dan lainnya. Anak akan merasa senang ketika berada pada sentra peran, yaitu pada sentra peran ini anak memainkan peran sesuai instruksi guru dan melibatkan teman lainnya untuk memainkan sebuah peran sehingga membuat anak dapat berinteraksi dan berkomunikasi langsung dengan lawan bicaranya. Sementara ketika anak masuk dalam sentra persiapan anak akan merasa jenuh mengikuti pembelajaran, dilihat dari ketika anak diajak menulis angka pada buku tulis anak akan memainkan buku dan pensilnya dan konsentrasinya tidak penuh ketika berada pada sentra persiapan.

Maka dari itu, dibutuhkan pembelajaran yang disesuaikan dengan kebutuhan anak agar anak merasa nyaman dan senang mengikuti pembelajaran, mengingat anak tunagrahita tidak dapat menerima pendidikan maupun pengajaran secara abstrak, maka diperlukan suatu strategi atau metode dalam menstimulasi perkembangannya. Salah satu metode yang dapat menstimulasi kemampuan bahasa lisan anak adalah metode yang dapat menarik minat dan perhatian anak, tentunya metode ini dilakukan dengan bermain karena sesuai karakteristik anak yang sangat menyukai bermain, metode yang akan digunakan dalam penelitian ini adalah metode sosiodrama.

Metode sosiodrama merupakan sebuah metode belajar yang dapat menciptakan pemahaman mendalam kepada anak usia dini untuk membentuk dan menciptakan pengalaman hidup bagi mereka serta bertujuan mengeksplorasi ideide baru dan konsep-konsep yang mereka pelajari. Metode sosiodrama memiliki banyak kelebihan, karena dalam pelaksanaannya anak akan belajar menyimak cerita guru (naskah) yang akan diperankan untuk kemudian anak akan berbicara dengan temannya yang menjadi lawan mainnya (Maimunah, 2012:4). Metode sosiodrama ini juga meningkatkan keterampilan komunikasi peserta didik untuk menyampaikan ide, pertanyaan, dan harapannya (Anggarasari, 2017:3). Metode sosiodrama merupakan pengembangan dari metode bermain. Dalam metode ini guru berperan sebagai fasilitator, pengarah, dan pengamat permainan. Guru yang mengarahkan dan bertanggung jawab pada kegiatan awal bermain anak. Guru pula yang memberikan motivasi, mengajukan pertanyaan, dan memberikan komentar agar anak dapat bebas mengekspresikan gagasan dan pemikirannya, sehingga anakanak mengetahui bagian mana yang masih membutuhkan eksplorasi lebih dalam (Inten, 2017:113). Metode sosiodrama mempunyai banyak kelebihan, karena dalam pelaksanaannya anak akan belajar menyimak cerita guru (naskah) yang akan diperankan untuk kemudian anak akan berbicara dengan temannya yang menjadi lawan mainnya. Dengan demikian kemampuan bahasa anak akan berkembang. Selain itu metode sosiodrama merupakan kegiatan yang menyenangkan dan akan mampu mengurangi rasa malu anak mengembangkan daya imajinasi anak. Sehingga perkembangan bahasa anak akan bisa meningkat dengan baik (Maimunah. 2012:4). Smilansky (Mutiah, 2010:144), 
mengamati bahwa bermain sosiodrama memiliki beberapa elemen:

a) Bermain dengan melakukan imitasi. Anak bermain pura-pura dengan melakukan peran orang di sekitarnya, dengan menirukan tingkah laku dan pembicaraannya.

b) Bermain pura-pura seperti suatu objek. Anak melakukan gerakan dan menirukan suara yang sesuai dengan objeknya, misalnya anak pura-pura menjadi mobil sambil lari dan menirukan suara mobil.

c) Bermain peran dengan menirukan gerakan. Misalnya, bermain menirukan pembicaraan antara guru dan murid atau orang tua dengan anak.

d) Persisten. Anak melakukan kegiatan bermain dengan tekun sedikitnya selama 10 menit. Terjadi interaksi paling sedikit ada dua orang dalam satu adegan, dan pada setiap adegan ada komunikasi verbal antara anak yang bermain.

Smilansky (Latif, 2013:210), ciri-ciri main peran sesuai dengan elemen diatas adalah sebagai berikut: anak meniru sebuah peran, anak tetap pada peran untuk beberapa menit, anak memakai tubuh dan objek atau merepresentasikan imajinasinya dengan objek dan orang, anak berinteraksi dengan anak lain, dan anak bertukar kata.

Definisi penggunaan terapi drama ini menggunakan improvisasi, bermain peran, mimik, musik, dan gerakan, mengkisahkan cerita, topeng dan ritual, wayang, bermain teater dan naskah drama. Terapi ini dapat membangun kepercayaan diri, meningkatkan kesadaran diri, ketenangan dan tanggung jawab, dan beroperasi pada berbagai tingkat seperti fisik, emosional, imajinasi, dan sosial (Crimmens, 2006:10).

Berdasarkan telaah kasus yang sudah dipaparkan sebelumnya maka diadakan penelitian menggunakan metode sosiodrama sebagai perlakuan yang diuji pengaruhnya terhadap kemampuan komunikasi verbal anak tunagrahita di PAUD Dharma Wangsa Denpasar. Sehubungan dengan hal tersebut, dirancanglah penelitian yang berjudul "Pengaruh Metode Sosiodrama terhadap Kemampuan Komunikasi Verbal Anak dengan Tunagrahita di PAUD Dharma Wangsa
Denpasar Barat Tahun Pelajaran
2017/2018".

METODE

Penelitian ini dilaksanakan pada Tahun Pelajaran 2017/2018. Waktu penelitian dari penyusunan proposal, pengumpulan data, dan penyusunan skripsi dimulai bulan Pebruari-Mei 2018. Lokasi penelitian dilakukan disalah satu PAUD Inklusi, yakni di PAUD Dharma Wangsa Denpasar Barat. Penelitian ini bertujuan untuk memperoleh gambaran yang objektif mengenai pengaruh metode sosiodrama terhadap kemampuan komunikasi verbal anak dengan tunagrahita. Penelitian ini menerapkan metode sosiodrama di dalam kelas. Sesuai dengan tujuan penelitian tersebut, maka penelitian ini tergolong sebagai penelitian eksperimen. Metode eksperimen merupakan kegiatan percobaan untuk meneliti suatu peristiwa atau gejala yang muncul pada situasi tertentu. Penelitian ini menggunakan desain kasus tunggal (single case design), dimana penelitian ini memfokuskan pengaruh metode sosiodrama pada kemampuan bahasa lisan pada seorang anak tunagrahita. Dengan kata lain, subjek yang diteliti dalam penelitian ini adalah tunggal.

Pada penelitian kasus tunggal (single case design), digunakan desain A-BA. Desain A-B-A merupakan salah satu pengembangan dari desain dasar $A-B$, desain A-B-A telah menujukkan adanya hubungan sebab akibat antara variabel terikat dan variabel bebas. Prosedur dasarnya tidak banyak berbeda dengan disain A-B, hanya saja telah ada pengulangan fase baseline. Setelah semua data dalam penelitian ini terkumpul, maka dilakukan analisis data. Dalam penelitian ini, digunakan analisis secara visual (visual inspection), dimana analisis secara visual ini mengintepretasikan data hasil pengukuran dengan menggunakan grafik secara akurat dan bermakna, pada dalam maupun antar kondisi yang dilibatkan (Sunanto, 2005:45).

Metode pengumpulan data yang dilakukan dalam penelitian ini, yaitu menggunakan metode observasi dan wawancara. Observasi merupakan pengamatan yang dilakukan secara langsung dan alamiah untuk mengetahui 
sejauh mana peningkatan kemampuan komunikasi verbal pada anak setelah diterapkan metode sosiodrama. Instrumen yang digunakan dalam penelitian ini adalah lembar observasi dengan teknik checklist. Wawancara dilakukan kepada guru serta orang tua (ayah/ibu) anak dengan maksud untuk memperoleh data serta informasi mengenai kemampuan komunikasi verbal anak dengan tunagrahita sebelum dan sesudah diterapkan metode sosiodrama.

Instrumen yang digunakan pada penelitian dibuat sedemikian rupa sesuai dengan fakta di lapangan dan sesuai dengan data yang telah diperoleh agar menghasilkan data yang akurat. Maka dari itu, untuk memperoleh data yang akurat sesuai dengan ketepatan data di lapangan maka dilakukan uji validitas isi untuk menguji kemampuan instrumen. Untuk menguji instrumen lebih lanjut, digunakan pendapat dari penguji (judgment experts) yaitu dosen yang memiliki keahlian dalam bidang mengenai kajian penelitian ini serta guru kelompok $A$ dan guru kelompok $B$ di PAUD Dharma Wangsa Denpasar dan tentunya dikonsultasikan terlebih dahulu. Dalam hal ini setelah instrumen dikonstruksi tentang aspek-aspek yang diukur dengan berlandaskan teori tertentu.

Reliabilitas sangat diperlukan dalam penelitian. Reliabilitas data penelitian sangat menentukan kualitas hasil penelitian (Sunanto, 2005:28). Reliabilitas data penelitian ditentukan dari interobserver agreement, data diperoleh dengan membandingkan penilaian dua observer dalam mengamati skor perkembangan kemampuan komunikasi verbal anak yang dilihat dari kegiatan anak sehari-hari. Penelitian melibatkan lebih dari satu observer dengan tujuan untuk mengurangi subjektivitas hasil observasi.

\section{HASIL DAN PEMBAHASAN}

Pada penelitian eksperimen kasus tunggal, perbandingan skor dilakukan pada satu subjek tetapi dalam kondisi yang berbeda. Kondisi yang dimaksud adalah kondisi baseline 1 (kondisi sebelum diberikan treatment/perlakuan), kondisi intervensi (kondisi saat diberikan treatment/perlakuan), serta kondisi baseline 2 (kondisi setelah dihentikannya treatment/perlakuan). Dari perolehan skor dapat diketahui perbandingan dari setiap kondisi. Oleh karena itu, analisis kuantitatif dilakukan dengan memperbandingkan hasil pengukuran subjek pada kondisi baseline 1, kondisi treatment, dan kondisi baseline 2 . Penyajian data secara visual di tiap-tiap kondisi dalam penelitian tersebut dapat dipaparkan dalam grafik berikut.

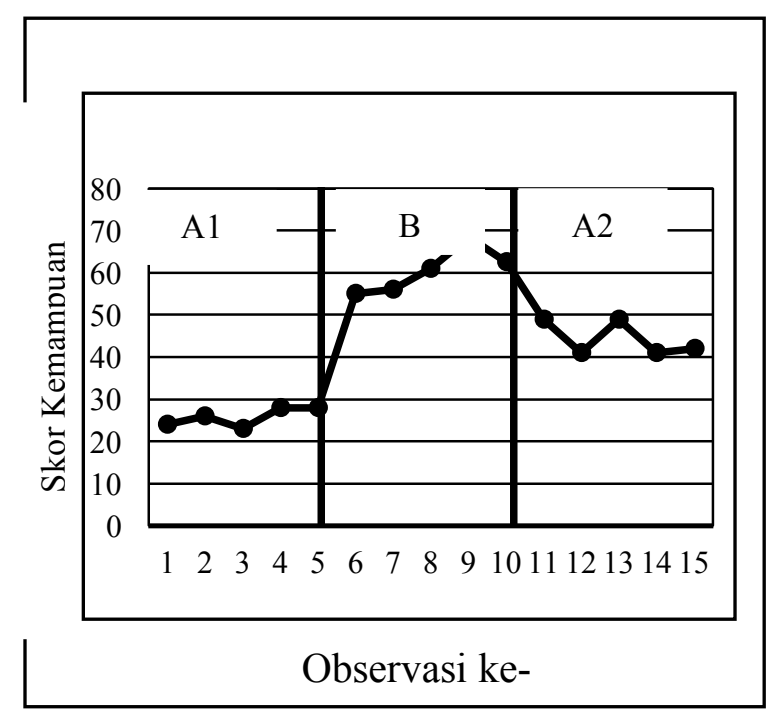

Gambar 1. Kemampuan Komunikasi Verbal
Subjek

Kemampuan komunikasi verbal anak dengan tunagrahita pada fase baseline 1 (A1) memiliki rerata 25,8 dan ada kecenderungan memburuk sebesar 2 poin. Frekuensi kemampuan komunikasi verbal anak dengan tunagrahita pada fase ini adalah dalam rentang 23-28. Kemampuan komunikasi verbal anak dengan tunagrahita meningkat saat diberikan treatment metode sosiodrama (B), yakni dengan rerata 60,6. Kemampuan komunikasi verbal anak dengan tunagrahita menunjukkan peningkatan sebesar 15 poin. Frekuensi kemampuan komunikasi verbal anak dengan tunagrahita pada fase ini adalah dalam rentang 42-70. Tetapi, pada fase baseline 2 (A2) terdapat perubahan kembali, yakni penurunan kemampuan komunikasi verbal anak dengan tunagrahita setelah treatment dihentikan dengan rerata 44,4 dan frekuensi fase ini dalam rentang 42-49. 
Rentang stabilitas pada fase baseline (A1) sebesar $60 \%$. Pada fase ini peneliti hanya memperoleh skor dalam waktu 5 hari. Keterbatasan waktu dalam penelitian membuat peneliti harus memanfaatkan waktu selama penelitian untuk benar-benar melihat kemampuan subjek dan apakah terdapat peningkatan pada fase ini.

Pada fase treatment (B), dengan rentang $80 \%$. Hal ini dikarenakan batas waktu penelitian sangat minim dan keadaan serta kondisi ruang lingkup pembelajaran yang kurang kondusif membuat penelitian menghentikan data pada hari kelima penerapan metode sosiodrama. Penerapan metode sosiodrama dihentikan selain karena keterbatasan waktu dan kondisi ruang lingkup pembelajaran yang kurang kondusif, juga karena dilihat dari perolehan rerata skor yang meningkat dari fase baseline (A1) sebesar 25,8 dan meningkat pada fase treatment sebesar 60,6 . Hal ini menunjukkan bahwa terdapatnya pengaruh metode sosiodrama terhadap kemampuan komunikasi verbal subjek.

Fase baseline (A2) dengan rentang $60 \%$. Pada fase ini, peneliti melihat pengaruh setelah penerapan metode sosiodrama dihentikan apakah terjadi perubahan pada subjek dan fase ini dilakukan selama 5 hari. Ternyata setelah penerapan metode sosiodrama dihentikan, dilihat penurunan rerata skor menjadi 44,4. Karena penerapan metode sosiodrama dihentikan, subjek tidak mendapatkan kembali stimulasi khusus yang diberikan selama fase penerapan. Tetapi, terjadi peningkatan kemampuan komunikasi verbal subjek dilihat dari fase baseline (A1) ke fase baseline (A2) setelah metode sosiodrama dihentikan. Jadi, terjadi peningkatan dan kecenderungan membaik pada kemampuan komunikasi verbal subjek.

Penerapan metode sosiodrama dilaksanakan secara berturut-turut, yakni pada tanggal 9 April-27 April 2018. Fase baseline 1, treatment, dan fase baseline 2 dilakukan masing-masing sebanyak 5 kali. Dalam penelitian ini, peneliti mengukur kemampuan komunikasi verbal subjek dengan menggunakan 18 indikator yang tiap indikatornya diukur setiap harinya. $\begin{array}{lllr}\text { Sesuai } & \begin{array}{c}\text { dengan } \\ \text { kemampuan }\end{array} & 18 & \text { indikator } \\ \text { kemunikasi } & \text { verbal subjek, } \\ \text { terdapat } & \text { peningkatkan } & \text { kemampuan }\end{array}$ komunikasi verbal subjek. Setiap indikator mengalami peningkatan pada fase treatment (B). Peningkatan skor kemampuan komunikasi verbal subjek sangat terlihat pada setting permainan baik komunikasi subjek dengan guru maupun komunikasi subjek dengan teman sebaya. Pada setting permainan umumnya kosa kata yang diungkapkan menuju pada kosa kata sederhana seperti mengajak bermain, bertanya mengenai permainan, maupun ingin mengikuti permainan. Cakupan permainan sangat luas sesuai dengan karakteristik anak usia dini yang suka bermain, maka pada setting permainan, kemampuan komunikasi verbal subjek paling banyak menunjukkan peningkatan secara bertahap, karena ketika bermain subjek akan spontan mengungkapkan kosa kata yang diketahuinya. Hal ini sejalan dengan penelitian Sumandari (2016), mengatakan bahwa bahasa memiliki peranan yang sangat penting dalam setiap aktivitas anak. Melalui bahasa anak dapat berkomunikasi, berinteraksi, dan mengekspresikan emosi yang dirasakannya. Sebagian besar aktivitas anak adalah bermain. Dengan bermain segala aspek perkembangan anak dapat distimulasi dengan baik. Dengan bermain, subjek dapat meningkatkan kosa kota yang dimilikinya serta beberapa kosa kata yang belum dipahami dan diketahui harus distimulasi secara optimal. Setting permainan sangat mendukung perkembangan komunikasi subjek. Banyak permainan yang dapat dilakukan untuk meningkatkan kemampuan bahasa terutama pada komunikasi verbal. Sejalan dengan penelitian Widiawati (2017), mengatakan metode sosiodrama akan menuntun anak untuk berolah bahasa dengan baik, anak akan berlatih konsentrasi untuk menyimak jalannya cerita untuk kemudian anak akan mengungkapkan isi pikirannya ke dalam bahasa lisan (dialog) dengan tokoh lainnya, dengan begitu anak akan berlatih berdialog, berdiskusi dengan orang lain ini sangat penting dalam peningkatan bahasa anak. Febrisma (2013), mengatakan bermain peran ini digunakan 
untuk meningkatkan kosa kata anak. Seperti yang diketahui bahwa kosa kata merupakan bagian penting dari bahasa. Semakin banyak kosa kata yang dimiliki semakin mudah anak-anak dapat berinteraksi. Tetapi, kesulitan dalam penerapan metode ini adalah subjek sulit mengungkapkan kata atau kalimat sesuai naskah yang dipandu Ibu guru, karena subjek malu dan merasa tidak percaya diri. Subjek akan terus menatap Ibu guru ketika naskah dibacakan. Perlu waktu berulang kali agar subjek mau mengungkapkan kata-kata sesuai naskah yang diucapkan Ibu guru. Pada akhirnya, subjek senang dan gembira setelah bermain sosiodrama.

Penerapan metode sosiodrama memberikan efek positif pada subjek, yakni ketika metode sosiodrama selesai dimainkan subjek akan merasa lega dan dapat mengungkapkan ekspresinya. Beberapa kosa kata baru yang diterima subjek sesuai dengan setting permainan dalam komunikasi dengan guru mampu diucapkan subjek dengan baik, walaupun terkadang terdengar tidak jelas atau ada beberapa huruf yang hilang dalam pengucapannya. Dalam setting permainan, yakni komunikasi dengan guru, subjek mampu mengungkapkan kembali dengan sendirinya kosa kata yang diperoleh setelah penerapan sosiodrama.

Berdasarkan pemaparan diatas, bahwa dalam setting permainan, komunikasi anak dengan guru juga komunikasi anak dengan teman sebaya memiliki peningkatan yang cukup signifikan dibandingkan dalam setting respon/panggilan, komunikasi anak dengan guru juga komunikasi anak dengan teman sebaya karena kemampuan komunikasi verbal anak akan mengalami perkembangan secara bertahap, jika distimulasi dengan berbagai permainan dan melalui bermain.

Dapat ditarik kesimpulan, bahwa kemampuan komunikasi verbal subjek mengalami peningkatan baik dalam pemeroleh kosa kata dan mengungkapkannya bahasa lisan, yang dikarekan oleh penerapan metode sosiodrama yang sesuai dengan karakteristik anak yaitu bermain. Melalui bermain sosiodrama subjek dapat mengungkapkan ekspresinya dan merasa gembira sehingga kemampuan komunikasi verbal subjek mengalami peningkatan setiap harinya secara bertahap sesuai dengan apa yang diperoleh anak melalui permainan dan bermain.

\section{PENUTUP}

Hasil analisis data menunjukkan bahwa terjadi peningkatan kemampuan komunikasi subjek dari fase baseline (A1) dengan rerata 25,8 menjadi 60,6 pada saat diterapkannya treatment pada fase penerapan (B), dan menurun kembali pada fase baseline (A2) saat penerapan metode sosiodrama dihentikan dengan rerata 44,4. Berdasarkan hasil penelitian tersebut, dapat disimpulkan bahwa metode sosiodrama berpengaruh terhadap meningkatnya kemampuan komunikasi verbal pada anak tunagrahita di PAUD Dharma Wangsa Denpasar Barat.

Berdasarkan analisis data yang telah disajikan dalam Bab IV, dapat disimpulkan bahwa metode sosiodrama berpengaruh terhadap peningkatan kemampuan komunikasi verbal anak dengan tunagrahita di PAUD Dharma Wangsa. Peningkatan kemampuan komunikasi verbal anak dengan tunagrahita dapat dilihat pada pengukuran fase baseline 1 (A1) dengan fase treatment/intervensi (B1).

Berdasarkan simpulan diatas, adapun beberapa saran yang ingin disampaikan sebagai berikut.

Bagi Guru. Metode sosiodrama sebaiknya rutin diberikan dalam setiap minggunya agar anak terus berlatih kemampuan komunikasi verbalnya. Serta dalam penerapan metode sosiodrama, guru harus selalu memberikan bimbingan dan arahan yang jelas pada anak, khususnya pada anak yang memang dianggap kurang dalam berkomunikasi.

Bagi Orang Tua. Sesuai dengan pembelajarn yang diterapkan di sekolah, maka orang tua juga memiliki peran penting di rumah untuk meningkatkan kemampuan komunikasi verbal anak. Orang tua harus selalu membimbing dan menstimulasi dengan bercakap-cakap atau bercerita dengan anak.

Peneliti Lain. Bagi peneliti lain atau peneliti selanjutnya, diharapkan mampu mengembangkan kembali metode 
sosiodrama agar lebih menarik dan bervariasi untuk meningkatkan permasaahan komunikasi pada anak didik yang ditemukan di TK nantinya.

\section{DAFTAR RUJUKAN}

Abdurahman S, Maman. 2017. Pembelajaran Berbicara bagi Siswa dengan Hambatan Kecerdasan. Universitas Pendidikan Indonesia. JASSI_anakku Volume 18 Nomor 1, Juni 2017. Tersedia dalam: http://ejournal.upi.edu/index.php/jassi/ar ticle/download/7659/4930 (Diakses pada tanggal 21 Januari 2018)

Anggarasari, Nandhini Hudha. 2017. Perbedaan Strategi Pembelajaran Sosiodrama dan Presentasi dalam Proses Pembelajaran. Tasikmalaya: Universitas Muhammadiyah Tasikmalaya. Early Childhood: Jurnal Pendidikan. Tersedia dalam: https://journal.umtas.ac.id/index.php/E ARLYCHILDHOOD/article/download/5 $1 / 46$ (Diakses pada tanggal 20 Januari 2018)

Aziz, Safrudin. 2015. Pendidikan Seks Anak Berkebutuhan Khusus. Yogyakarta: Penerbit Gava Media

Crimmens, Paula. 2006. Drama Therapy and Storymaking in Special Education. London: Jessica Kingsley Publishers

Febrisma, Nurilya. 2013. Upaya Meningkatkan Kosa Kata Melalui Metode Bermain Peran Pada Anak Tunagrahita Ringan (PTK Kelas DV di SLB Kartini Batam). Batam: SLB Kartini. E-Jupekhu (Jurnal IImiah Pendidikan Khusus) Volume 1 Nomor 2 mei 2013. Tersedia dalam: http://ejournal.unp.ac.id/index.php/jupe khu/article/download/1150/999. (Diakses pada tanggal 26 Pebruari 2018)

Inten, Dinar Nur. 2017. Pengembangan Keterampilan Berkomunikasi Anak Usia Dini melalui Metode Bermain Peran. Bandung: Universitas Islam Bandung. MediaTor, Vol 10 (1), Juni 2017, 109-
$120 . \quad$ Tersedia dalam:

http://ejournal.unisba.ac.id/index.php/m ediator/article/download/2712/pdf

(Diakses pada tanggal 19 Januari 2018)

Latif, Mukhtar dkk. 2013. Orientasi Baru Pendidikan Anak Usia Dini: Teori dan Aplikasi. Jakarta: Kencana Prenadamedia Group

Maimunah, Siti. 2012. Peningkatan Kemampuan Bahasa Anak Melalui Metode Sosiodrama Bagi Anak Kelompok B1 Pada Taman Kanakkanak Aisyiyah Bustanul Athfal Pulosari 1 Kebakkramat. Surakarta: Universitas Muhammadiyah Surakarta. Tersedia dalam:

http://eprints.ums.ac.id/22903/19/Publik $\underline{\text { asi skripsi.pdf (diakses tanggal } 12}$ Januari 2018)

Mastuti, Devi. 2014. Kesiapan Taman Kanak-kanak dalam Penyelenggaraan Kelas Inklusi Dilihat Program Kegiatan Pembelajaran. Journal of Early Childhood Education Papers. Semarang: Universitas Negeri Semarang. Tersedia dalam: https://journal.unnes.ac.id/sju/index.php /belia/article/download/3274/3007 (diakses pada tanggal 15 Januari 2018)

Nuraeni, 2014. Pendidikan Inklusi di Lembaga Pendidikan Anak Usia Dini. Mataram: IKIP Mataram. Tersedia dalam:

http://lppm.ikipmataram.ac.id/wpcontent/uploads/2015/03/Nuraeni.Pendidikan-Inklusi-di-Lembaga-PAUD.Jurnal-Kependidikan-Edisi-Desember2014-Vol.-13-No.-4.pdf (Diakses pada tanggal 15 Januari 2018)

Peraturan Menteri Pendidikan dan Kebudayaan Republik Indonesia Nomor 137 Tahun 2014 Tentang Standar Nasional Pendidikan Anak Usia Dini, 2013.

Smith, J. David. 2006. Inklusi Sekolah Ramah untuk Semua. Bandung: Penerbit Nuansa 
Sumandari. 2016. Penerapan Metode Sosiodrama untuk Meningkatkan Kemampuan Berbicara Anak Kelompok B Di RA Baitul Muta'Allim Desa Tegalinggah. Singaraja: Universitas Pendidikan Ganesha. Jurnal Pendidikan Guru Pendidikan Anak Usia Dini Volume 4. No. 3 Tahun 2016. Tersedia dalam: https://ejournal.undiksha.ac.id/index.p hp/JJPAUD/article/download/8902/57 $\underline{43}$ (Diakses pada tanggal 5 Juli 2018)

Sunanto, Juang dkk. 2005. Pengantar Penelitian Subyek Tunggal. Tsukuba: CRICED University of Tsukuba.

Widiawati, Gusti Ayu Kade Hepi. 2017. Pengaruh Metode Sosiodrama Bermuatan Cerita Rakyat Terhadap Kemampuan Berbicara pada Anak. Singaraja: Universitas Pendidikan Ganesha. Jurnal Pendidikan Guru Pendidikan Anak Usia Dini Volume 5 No. 1 Tahun 2017. Tersedia dalam: https://ejournal.undiksha.ac.id/index.p $\mathrm{hp/JJPAUD/article/viewFile/11432/732}$ $\underline{8}$ (Diakses pada tanggal 5 Juli 2018)

Yosiani, Novita. 2014. Relasi Karakteristik Anak Tunagrahita dengan Pola Tata Ruang Belajar di Sekolah Luar Biasa. E-Journal Graduate Unpar. Vol. 1, No.2. Universitas Katolik Parahyangan. Tersedia dalam: http://download.portalgaruda.org/articl e.php?article $=165834 \& v a l=6053 \%$ title =Relasi\%20Karakteristik\%20Anak\%2 0Tunagrahita\%20Dengan\%20Pola\%2 0Tata520Ruang\%20Belajar\%20di\%20 Sekolah\%20Luar\%20Biasa (Diakses pada tanggal 21 Januari 2018) 